INDEPENDENT JOURNAL OF MANAGEMENT \& PRODUCTION (IJM\&P)

http://www.ijmp.jor.br

v. 12, n. 6, Special Edition ISE, S\&P - November 2021

ISSN: 2236-269X

DOI: 10.14807/ijmp.v12i6.1762

\title{
PROBLEM ASPECTS OF APPLICATION BY STATE ENTERPRISES OF INTERNATIONAL STANDARDS OF ACCOUNTING AND REPORTING IN RENTAL OPERATIONS
}

Serhii Rohoznyi Kyiv National Economic University named after Vadym Hetman, Ukraine

E-mail: s_rogozny@ukr.net

Iryna Parasii-Verhunenko Kyiv National University of Trade and Economics, Ukraine E-mail: impverh@gmail.com

Petro Kutsyk Lviv University of Trade and Economics, Ukraine E-mail: petrokutsyk55@gmail.com

Olena Biriuk Kyiv National Economic University named after Vadym Hetman, Ukraine E-mail:biruk_kneu@ukr.net

Olena Kolesnikova National University of Life and Environmental Sciences of Ukraine, Ukraine E-mail: kolesnikova.o.m@nubip.edu.ua

Svitlana Holovatska IJTM\&E Lviv University of Trade and Economics, Ukraine E-mail: svitlana-14-10@ukr.net

Submission: 8/9/2021

Revision: 9/13/2021

Accept: 9/22/2021

\section{ABSTRACT}

The purpose of the article is to determine the peculiarities of public sector enterprises' use of international and national accounting and financial reporting standards governing the accounting of lease transactions, study the impact of their provisions on financial reporting indicators, substantiation of the most acceptable lease accounting models for public sector enterprises. The information base of the empirical study was the data of the official website of the Ministry of Economic Development, Trade and Agriculture of Ukraine for 20132020. 
INDEPENDENT JOURNAL OF MANAGEMENT \& PRODUCTION (IJM\&P)

http://www.ijmp.jor.br

v. 12, n. 6, Special Edition ISE, S\&P - November 2021

ISSN: 2236-269X

DOI: 10.14807/ijmp.v12i6.1762

Methodical and methodological basis of accounting for lease transactions were the provisions of P (S) of Accounting 14, NP (S) of Accounting SS 126, IPSASB 13, IAS 17, IFRS 16. In the study used such techniques as comparison, l, time series, structural -dynamic and coefficient analysis. The essence of the concept of "lease" is clarified on the basis of a comparative analysis of its various definitions given in international, national standards of accounting and financial reporting for business entities, public sector entities, as well as in other regulations. The conceptual model of rent accounting for P (S) of Accounting 14, NP (S) of Accounting SS 126, IPSASB 13, IAS 17 and IFRS 16 is considered, the problematic aspects of its application in the accounting practice of domestic state enterprises are identified. Discussion issues concerning the application of the provisions of IAS 17 are highlighted, which include: the lack of a financial component in rental costs; lack of information in the financial statements about lease obligations not incurred by the company; Insufficient information in the financial statements about the existence of the asset to which the lessee has the right to use. The results of the study are to identify the key problems of the lease accounting model in accordance with IAS 17 for state-owned enterprises and make suggestions for their solution. Recommendations for assessing the impact of the lease accounting model in accordance with IFRS 16 on the financial statements of the lessee have been developed. The main directions of elimination of obstacles to the implementation of IFRS in the domestic accounting practice concerning the lease operations of state-owned enterprises are identified.

Keywords: international standards of accounting and financial reporting; national accounting standards; rent; tenant; landlord; public sector; assets; obligation

\section{INTRODUCTION}

Ensuring the effective integration of Ukraine into the world community, finding partners and attracting foreign investment - all this requires bringing economic information and, in particular, accounting and reporting, to international requirements. Domestic and international experts emphasize that the universal language of business and a collection of the best accounting policies today are International Financial Reporting Standards (hereinafter IFRS).

The use of IFRS as a conceptual framework for the preparation of financial statements helps to increase its transparency, quality and reliability. For public sector enterprises, 
DOI: 10.14807/ijmp.v12i6.1762

improving the quality of financial reporting is also extremely important, especially in the context of forming a basis for effective analytical work with financial data.

Tasks and goals of functioning of state enterprises differ from the objectives of private enterprises without a share of state ownership, and therefore, the features of management and requests for information component of the financial statements of such enterprises will be different. The procedure for accounting for lease transactions and their reflection in the financial statements, which is regulated by national and international standards, contains many contradictions and inconsistencies. Moreover, they do not take into account the peculiarities of the activities of state-owned enterprises related to the form of ownership.

The purpose of the article is to determine the peculiarities of public sector enterprises' use of international and national accounting and financial reporting standards governing the accounting of lease transactions, study the impact of their provisions on financial reporting indicators, substantiation of the most acceptable lease accounting models for public sector enterprises.

\section{LITERATURE REVIEW}

The potential benefits of applying IFRS for public sector enterprises in academia have been discussed long before they were actively disseminated in Ukraine. Thus, back in 2010, Khomuliak (2010) noted that the introduction of IFRS is also important in the public sector in order to adapt the organizational and methodological framework of accounting to international requirements. Further discussion on the relevance of international standards in the public sector continued.

Thus, Tsenkler, Vyhivska and Makarovych (2019) emphasize that the reporting, formed according to international standards, allows comparing the economic development of different countries and identifying the most promising economies for investment.

Problematic issues regarding the removal of obstacles to the implementation of international financial reporting standards in the accounting practice of state-owned enterprises of Ukraine were raised in the study of Lovinska (2020), which focused on their special status due to state ownership and their functional orientation - performing certain social functions. She notes that, attracting potential investments for state-owned enterprises, the information base of which is financial reporting, cannot be a priority. The presence of state control determines the peculiarities of accounting and reporting of state-owned 
DOI: 10.14807/ijmp.v12i6.1762

enterprises, which in foreign countries are sufficiently fully regulated by national legislation, which does not contradict international standards of accounting and reporting.

The problems of harmonization (convergence) of the provisions of national accounting standards and reporting with international ones are the subject of close attention of many foreign scholars, especially those countries that have recently started using IFRS in their accounting practices. Thus, Chinese scientists (Qu, Zhang, 2010) proposed a new methodological approach to the study of the level of convergence of national and international accounting and reporting standards based on fuzzy cluster analysis, according to which different standards were grouped into appropriate clusters by similarity. This approach to measuring the level of convergence of national and international accounting standards allows us to focus on ways to improve them in order to eliminate the relevant differences.

Other Chinese scholars (Chin, Hengal \& Noronhab, 2011) based on a comparative analysis of financial reporting indicators compiled according to the rules of national and international accounting and reporting standards, concluded that they have virtually no significant differences in their values, in particular the value of net company assets, operating profit, pre-tax profit, net profit and others. This indicates the maximum approximation of the provisions of Chinese national accounting standards to international ones.

Given the peculiarities of the object of our study - lease transactions, it should be noted that the methodological principles of their accounting, laid down in IAS 17 "Leases" and IFRS 16 "Leases" make significant adjustments to the order of their reflection in the financial statements, in particular in the balance sheet. A comparison of accounting models for these two standards revealed differences in the recognition of balance sheet items, the statement of comprehensive income and the statement of cash flows (Aurora, 2019).

Analysing the results of the impact of the application of IFRS 16 "Leases" on credit risk assessments, American scientists (Vidovic et al., 2019) stated that the new approach to accounting for leases and the order of their reflection in the financial statements of assets and balance sheet liabilities change significantly, which in turn affects the results of assessing the creditworthiness of companies. Confirmation of the significant impact on the financial performance of operating lease capitalization companies and its benefits for management decisions has also been made by many other scholars (Natarajan \& Kuniparambil, 2019; Aurora, 2020). 
A similar conclusion was reached by South African scholars (Segal \& Naik, 2019), who based on information obtained in a public debate conducted jointly by the International Accounting Standards Board (IASB) and the South African Institute of Chartered Accountants (SAICA), confirmed that the application of IFRS 16 "Lease" lead to changes in the configuration of the balance sheet, and thus affects the liquidity and solvency of the enterprise.

U.S. researchers Milian Jonathan and Lee Jin analysed the benefits of ASC 842 in recognizing operating leases on the balance sheet, which were previously disclosed only in the notes to the financial statements. The study focuses on making it easier for investors to obtain rental information, as they have previously had to make a number of adjustments to obtain acceptable information (Jonathan \& Jin, 2020).

Morales-Díaz, José, Zamora-Ramírez and Constancio (2018) analysed 346 European companies in order to assess the impact of the application of IFRS 16 "Lease" on key financial indicators and found that the most sensitive to the transition between standards are the retail sector, transport, hotel sector, IT sector and services sector. ROA declined significantly in several sectors (households, material production, pharmaceuticals and the media). At the same time, significant differences in the results of the impact on key indicators were observed among individual companies within one sector. It is likely that companies with high leverage will try to reduce the number of leases to avoid leverage problems.

The sensitivity of the industry specifics of enterprises to information changes in financial statements due to the application of IFRS 16 is proven by the example of aviation enterprises, where the operating lease instrument is widely used. A survey of 15 European airlines confirmed the expected increase in total assets, non-current liabilities and a decrease in equity, which in turn affects ROA and ROE (Veverkova, 2019). Among the problematic aspects, the researcher highlighted the difficulty of full control over the use of the leased asset in the transport and logistics sector; a combination in one agreement of both the lease itself and the services for servicing the leased asset. Analysing the 35 largest Spanish companies, Pardo and Giner (2018) proved that with the new model of accounting for leases and the order of their reflection on the balance sheet, the value of liabilities increased by 20 billion or increased by $4.81 \%$, which inevitably leads to a change in ROE.

Japanese researcher Kusano (2020), continuing to study the impact of the application of the provisions of IFRS 16 "Leases" on changing the structure of balance sheet items, 
INDEPENDENT JOURNAL OF MANAGEMENT \& PRODUCTION (IJM\&P)

http://www.ijmp.jor.br

v. 12, n. 6, Special Edition ISE, S\&P - November 2021

ISSN: 2236-269X

DOI: 10.14807/ijmp.v12i6.1762

developed an opinion on its implications not only for assessing liquidity and solvency, but also for equity risk. The consequences of such influence are important, first of all, for decision-making by institutional investors on the feasibility of investing in the company.

The advantages of renting a property over its purchase are illustrated in a study by Musumeci Jim and O'Brien Thomas J., who concluded that differences in tenant and landlord borrowing rates may be a strong argument in favour of rent compared to buying (Musumeci \& O'Brien, 2019).

Noting that the application of IFRS 16 improves the informativeness of financial statements for decision-making by managers, directors, bankers, financial analysts, Dutch scientists (KintsL \& Spoor, 2018) emphasize the difficulty of its interpretation and the need to develop additional analytical indicators for prudent management and investment decisions.

Chinese scientists Zhang and Liu (2020) analysed the positive and negative effects of using the provisions of IFRS 16 "Leases" for state-owned enterprises. They concluded that the new rules for accounting for lease transactions increase the book value of the enterprise's assets, which has a positive impact on the mechanism of preferential lending or additional financing by the state. On the other hand, there is a decrease in the share of equity, which reduces the financial stability of tenant companies, and thus reduces their investment attractiveness.

Despite the growing attention of foreign and domestic scholars to these issues, it should be noted that the problems of using the provisions of IFRS 16 "Leases" by state enterprises require additional research and the need to harmonize their provisions with the methodology of current industry regulations and other regulations governing the accounting of lease transactions.

\section{DATA AND METHODOLOGY}

The information base of the empirical study was the data of the official website of the Ministry of Economic Development, Trade and Agriculture of Ukraine for 2013-2020. Methodical and methodological base for accounting for lease transactions were the Provisions of Standards of Accounting 14, NP (S) of Accounting SS 126, IPSASB 13, IAS 17, IFRS 16.

In the course of the research such methodical methods as comparison, modelling, time series, structural-dynamic and coefficient analysis were used. 
INDEPENDENT JOURNAL OF MANAGEMENT \& PRODUCTION (IJM\&P)

http://www.ijmp.jor.br

v. 12, n. 6, Special Edition ISE, S\&P - November 2021

ISSN: 2236-269X

DOI: 10.14807/ijmp.v12i6.1762

Comparative analysis was used in the study of the share of the public sector in the domestic economy by individual activities of companies.

The modelling technique was used to determine the most acceptable format for accounting for lease transactions for state-owned enterprises.

\section{RESULTS AND DISCUSSIONS}

Entities of the public sector of the economy in accordance with domestic law are entities that operate on the basis of state ownership only, as well as entities whose state share in the authorized capital exceed fifty per cent or is a value that provides the state with the right to decide impact on the economic activities of these entities (Aurora, 2016).

An important indicator for understanding the importance of the public sector is its share in the economy of Ukraine (Figure 1).

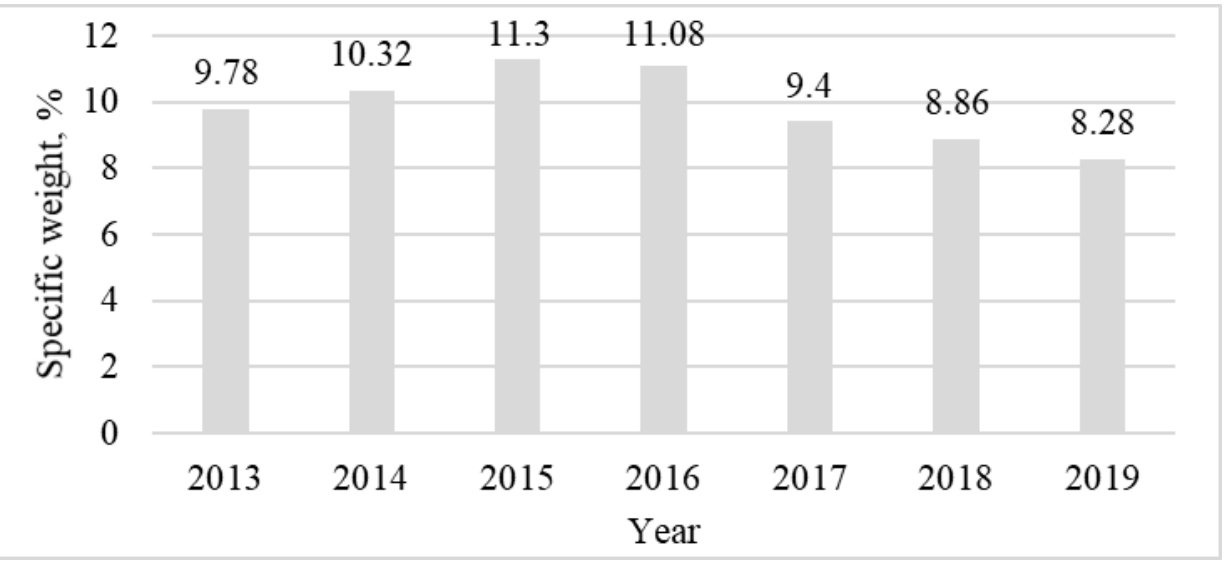

Figure 1: Dynamics of the share of the public sector of the economy in 2013-2019, \%

Source: created by the authors according to (Ofitsiinyi sait Ministerstva rozvytku ekonomiky)

The indicator is calculated and presented by the Ministry of Economic Development, Trade and Agriculture of Ukraine as the average of a number of 5 other indicators (share of public sector enterprises; share of sales; net profit; residual value of fixed assets and intangible assets, current assets; average number of employees). From Figure 1 it can be concluded that the share of the public sector in recent years is insignificant, but is declining.

Interim calculations for 2020 show a slightly higher figure $(11.8 \%$ in the first quarter and $11.5 \%$ in the first half). These indicators are not comparable to the annual ones, as they are not based on five basic indicators for calculation, but only three.

Therefore, final conclusions can be made only after the publication of annual data. However, the comparison with similar intermediate indicators last year confirms the thesis of 
INDEPENDENT JOURNAL OF MANAGEMENT \& PRODUCTION (IJM\&P)

http://www.ijmp.jor.br

v. 12, n. 6, Special Edition ISE, S\&P - November 2021

ISSN: 2236-269X

DOI: 10.14807/ijmp.v12i6.1762

reducing the share (for comparison, $13 \%$ in the first half of 2019, $13.8 \%$ in the first half of 2018).

Stasyshyn, Dubyk and Barska (2018) aptly note that the share of the public sector in a market economy is a variable, and its boundaries are quite mobile; and mobility, in turn, is associated with the centralization and decentralization of public and private sector capital. From the above statistics we understand that this is indeed the case. In any case, we have no reason to underestimate the strategic and national role of the public sector in Ukraine's economy. It should be noted that accounting and reporting activities for state-owned enterprises are as relevant as for private ones, and in some respects, they fall under a higher level of regulation. Therefore, they are subject to detailed consideration in the context of national and global areas of reporting improvement.

Recently, one of the leading trends in the development of the reporting tool in Ukraine is the expansion of the scope of IFRS. Public enterprises may also be IFRS-compliant if they meet the criteria of a public interest entity or other mandatory requirements.

In this context, a clear distinction should be made between a public institution and a state-owned enterprise. Thus, there is a separate system of standards in international practice that apply to public sector institutions and do not apply to financial and non-financial enterprises, accounting in which is organized by analogy with private sector enterprises.

The existence of independent International Public Sector Accounting Standards (IPSASB) is associated with a difference in accounting rules in public institutions compared to the traditional approaches of commercial companies. Currently in Ukraine, the modernization of reporting in the public sector is underway, within which 20 national regulations (standards) have been approved, which are developed on the basis of international standards, and methodological recommendations for their application. The implementation of the National Strategy for Modernization of the Accounting and Financial Reporting System in the Public Sector for the period up to 2025 continues and requires some thorough research (Pro orendu zemli).

In this study, we will focus on the part of the public sector that is represented by stateowned enterprises. The share of the public sector by sectors of the economy is given in Table 1. 
INDEPENDENT JOURNAL OF MANAGEMENT \& PRODUCTION (IJM\&P)

http://www.ijmp.jor.br

v. 12, n. 6, Special Edition ISE, S\&P - November 2021

ISSN: 2236-269X

DOI: 10.14807/ijmp.v12i6.1762

Table 1: The share of the public sector in the sphere of activity of enterprises

\begin{tabular}{|l|c|l|}
\hline \multicolumn{1}{|c|}{ Sectors of the economy } & The share of PS * & \multicolumn{1}{|c|}{ Examples of state-owned enterprises } \\
\hline $\begin{array}{l}\text { Transport, warehousing, postal and } \\
\text { courier activities }\end{array}$ & $29.4 \%$ & $\begin{array}{l}\text { JSC "Ukrainian Railways", 100\% of the shares belong } \\
\text { to the state represented by the Cabinet of Ministers of } \\
\text { Ukraine; } \\
\text { JSC "Ukrposhta", 100\% of the shares belong to the } \\
\text { state represented by the Ministry of Infrastructure of } \\
\text { Ukraine }\end{array}$ \\
\hline $\begin{array}{l}\text { Supply of electricity, gas, steam and } \\
\text { air conditioning }\end{array}$ & $28.6 \%$ & $\begin{array}{l}\text { SE "NAEK Energoatom”, 100\% of shares belong to } \\
\text { the state represented by the Ministry of Energy of } \\
\text { Ukraine } \\
\text { "NJSC Naftogaz of Ukraine”, 100\% of shares belong } \\
\text { to the state represented by the Cabinet of Ministers of } \\
\text { Ukraine }\end{array}$ \\
\hline $\begin{array}{l}\text { Mining and development of quarries } \\
\text { Agriculture, forestry and fisheries }\end{array}$ & $7.3 \%$ & $\begin{array}{l}\text { JSC “Agrarian Fund", 100\% of the shares belong to the } \\
\text { state represented by the Cabinet of Ministers of } \\
\text { Ukraine }\end{array}$ \\
\hline $\begin{array}{l}\text { Water supply; sewerage, waste } \\
\text { management }\end{array}$ & $3.8 \%$ & $\begin{array}{l}\text { SE "Dnipro-VDM", 100\% of shares belong to the state } \\
\text { represented by the Ministry of Economic Development } \\
\text { and Trade of Ukraine }\end{array}$ \\
\hline
\end{tabular}

Source: Compiled by the authors according to the Ministry of Economic Development, Trade and Agriculture of Ukraine (2019)

It should be noted that at present many state-owned enterprises have formally changed their form of ownership to non-state, the name does not include the term "state-owned enterprise”, instead of “joint-stock company”. However, in fact, the state is the $100 \%$ owner. As a rule, this is done in order to find investors and gain their trust, as well as to build a clear management system.

It will be recalled that after the update in 2017 of the Law "On Accounting and Financial Reporting in Ukraine” (Zakon №996-XIV) IFRS become mandatory for companies of public interest; public joint stock companies; business entities operating in the extractive industries. With this in mind, many of the companies listed above are clearly public interest entities and are a priori subject to IFRS reporting requirements. However, next to them, there is a large share of state-owned enterprises that report on UAS.

For example, the top 10 state-owned enterprises in terms of net profit in the first half of 2019 according to the Ministry of Economic Development, Trade and Agriculture of Ukraine (Ofitsiinyi sait Ministerstva rozvytku ekonomiky) included “Ukrinterenergo”, on the official website (Ofitsiinyi sait DP) which published reports on P (S) of Accounting. And there are many such examples.

Given the specifics of the activities of each of these sectors, in which a high share of public sector enterprises, potentially relevant for them are leases. The lease relationship is beneficial for both the tenant's position and the landlord's side. Thus, for the lessee, the purchase of too expensive an asset is not always financially feasible; instead, the lease is a 
INDEPENDENT JOURNAL OF MANAGEMENT \& PRODUCTION (IJM\&P)

http://www.ijmp.jor.br

v. 12, n. 6, Special Edition ISE, S\&P - November 2021

ISSN: 2236-269X

DOI: 10.14807/ijmp.v12i6.1762

convenient tool for saving money. For a lessor, the transfer of an asset for temporary use on a paid basis is also cost-effective if, for some reason, such an asset is not used in its own activities. The rules for reflecting lease transactions are governed by the following standards:

- P (S) of Accounting 14 "Rent" - for domestic enterprises that are not required by IFRS;

- NP (S) of Accounting PS 126 "Rent”- for domestic public sector entities;

- IAS 17 "Leases"- for domestic entities that are required by IFRS (applied until 2019);

- IFRS 16 "Lease”- for domestic enterprises that are required by IFRS (applicable from 01.01.2019);

- IPSASB 13 "Leases" is an international standard for accounting for leases in the public sector.

Understanding the peculiarities of the use of accounting and reporting rules defined by national and international standards of accounting and reporting on lease transactions for state-owned enterprises is based on the definition of the economic essence of the concept of "lease" (Table 2). As shown in Table 2 there are no significant differences between the interpretations of the lease in the regulations.

Table 2: The essence of the concept of "Lease" through the prism of different standards

\begin{tabular}{|c|c|c|}
\hline № & Source & $\begin{aligned} \text { The essence of the lease } \\
\end{aligned}$ \\
\hline \multicolumn{3}{|r|}{ Accounting and reporting standards } \\
\hline 1 & $\begin{array}{l}\text { P (S) of Accounting } \\
14 \text { "Lease" }\end{array}$ & $\begin{array}{l}\text { Lease - an agreement under which the lessee acquires the right to use a non-current } \\
\text { asset for a fee within the period agreed with the lessor. }\end{array}$ \\
\hline 2 & $\begin{array}{l}\text { NP (S) of Accounting } \\
\text { PS } 126 \text { "Lease" }\end{array}$ & $\begin{array}{l}\text { Lease - an agreement under which the lessee acquires the right to use a non-current } \\
\text { asset for a fee within the period agreed with the lessor. }\end{array}$ \\
\hline 3 & IAS 17 “Lease” & $\begin{array}{l}\text { A lease is an agreement under which the lessor transfers to the lessee, in exchange for } \\
\text { a payment or a series of payments, the right to use the asset for an agreed period of } \\
\text { time. }\end{array}$ \\
\hline 4 & IFRS 16 “Lease” & $\begin{array}{l}\text { A lease is an agreement, or part of an agreement, that transfers the right to use an asset } \\
\text { (the underlying asset) over a period of time in exchange for compensation. In this case, } \\
\text { the agreement is whether it contains a lease, if it transfers the right to control the use of } \\
\text { the identified asset for a certain period of time in exchange for compensation. }\end{array}$ \\
\hline 5 & IAS PS 13 “Lease” & $\begin{array}{l}\text { Lease - an agreement under which the lessor transfers to the lessee in exchange for a } \\
\text { payment or a series of payments the right to use the asset during the agreed period. }\end{array}$ \\
\hline \multicolumn{3}{|r|}{ Other sources } \\
\hline 6 & Tax Code of Ukraine & $\begin{array}{l}\text { Leasing (lease) transaction - a business transaction (other than chartering (charter) of } \\
\text { seagoing vessels and other vehicles) of a natural or legal person (lessor), which } \\
\text { provides for the provision of fixed assets for use by other natural or legal persons } \\
\text { (tenants) for a fee term. }\end{array}$ \\
\hline 7 & $\begin{array}{l}\text { Law of Ukraine "On } \\
\text { Lease of State and } \\
\text { Municipal Property" }\end{array}$ & $\begin{array}{l}\text { Lease is a real right to property, according to which the lessor transfers or undertakes } \\
\text { to transfer the property to the lessee for use for a fee for a certain period. }\end{array}$ \\
\hline 8 & $\begin{array}{l}\text { Law of Ukraine "On } \\
\text { Land Lease" }\end{array}$ & $\begin{array}{l}\text { Land lease is a term-based paid tenure and use of land required by the lessee for } \\
\text { business and other activities. }\end{array}$ \\
\hline
\end{tabular}

Source: summarized by the authors 
DOI: $10.14807 /$ ijmp.v12i6.1762

In particular, the common characteristics for all definitions are:

- lease object (but with different accents in the name - asset, non-current asset, underlying asset, property, fixed asset);

- interaction of two entities (tenant-landlord);

- the nature of the relationship between the entities (based on the contract);

- a certain period (the object is transferred for use for a period established by the contract);

- $\quad$ payment (the right to use the object is paid).

However, it should be noted that the definitions given in the TCU and the analysed Laws have more economic than accounting essence. Therefore, we separately analyse the definitions given exclusively in the standards (paragraphs 1-5 of Table 2).

A detailed analysis shows that IFRS 16 has some differences compared to other standards, in particular:

a) IFRS 16 emphasizes that the lease can be both the contract as a whole and its individual components (in this context, it is important to analyse the contracts in terms of their compliance with the requirements of the standard or recognition as outside its scope). Instead, the interpretation of the lease in accordance with P (S) of Accounting 14 uses the term "agreement", which is broader than the term "contract" in the interpretation of the lease in accordance with IFRS 16. We believe that in this case the specification of IFRS 16 is more appropriate.

b) In the analysis of compliance of the agreement with the conditions of IFRS 16, attention is shifted from the right of use to the right of control (in understanding the possibility of obtaining all benefits and determining how to use the leased object).

c) Emphasis is placed on the concept of "identified" and "underlying” asset as the core of the lease agreement (instead of the usual concepts of "non-current asset”, "fixed assets", "property"). In turn, the underlying asset means "the asset that is the subject of the lease, and the right to use which is transferred by the lessor to the lessee”.

From this initial analysis, it becomes clear that IFRS 16 differs both from the predecessor standard (IAS 17) and from other domestic and international standards in terms of more accurate consideration of the nature of lease transactions. These three characteristics are equally relevant and relevant to the leasing operations of state-owned enterprises. 
INDEPENDENT JOURNAL OF MANAGEMENT \& PRODUCTION (IJM\&P)

http://www.ijmp.jor.br

v. 12, n. 6, Special Edition ISE, S\&P - November 2021

ISSN: 2236-269X

DOI: 10.14807/ijmp.v12i6.1762

To support this thesis, we analyse other significant differences. Preliminarily, we conclude that the conceptual model of rent accounting for $\mathrm{P}$ (S) of Accounting 14, NP (S) of Accounting PS 126, IPSASB 13 is very similar in nature to IAS 17. It is on the basis of IAS 17 that the domestic P (S) of Accounting 14 was developed, and the preamble to IPSASB 13 explicitly states that it is based mainly on IAS 17. As for IPSASB, a mechanism for amending these standards has been launched, but we are currently considering the current version. Therefore, we consider it appropriate to compare these standards comprehensively with IFRS 16.

The most obvious difference between IFRS 16 and other standards is the approach to the classification of leases (Table 3).

Table 3: Classification of rent

\begin{tabular}{|c|c|c|}
\hline \multicolumn{2}{|c|}{$\begin{array}{c}\text { IAS 17, P (S) of Accounting 14, } \\
\text { NP (S) of Accounting PS 126, IPSASB } 13\end{array}$} & IFRS 16 \\
\hline $\begin{array}{l}\text { Position of } \\
\text { landlord }\end{array}$ & $\begin{array}{l}\text { The only approach for both the } \\
\text { lessee and the lessor: } \\
\text { the criterion - the distribution of } \\
\text { risks and rewards associated with the } \\
\text { ownership of the asset (leased } \\
\text { object) between the lessor and the } \\
\text { lessee: } \\
\text { - operating lease; } \\
\text { - financial lease. }\end{array}$ & $\begin{array}{l}\text { Common: operating and financial lease. } \\
\text { Excellent: } \\
\text { - updated concept of lease; } \\
\text { - expanding the range of information before } \\
\text { disclosure by the landlord; } \\
\text { - new requirements for sales agreements, } \\
\text { followed by rent and sublease on } \\
\text { - the procedure for accounting for lease } \\
\text { modifications has been clarified }\end{array}$ \\
\hline $\begin{array}{c}\text { Position of } \\
\text { Tenant }\end{array}$ & $\begin{array}{l}\text { The conditions for identifying the } \\
\text { type of lease are set out in } \\
\text { paragraphs } 10,11 \text { of IAS } 17 \text {; item } 4 \\
P(S) \text { of Accounting } 14 \text {; item } 4 \text {; NP } \\
\text { (S) of Accounting PS 126; } \\
\text { paragraphs } 13,14 \text { of IPSASB } 13 \text {. }\end{array}$ & $\begin{array}{l}\text { There is no distribution. If the conditions of } \\
\text { recognition are met - it is a lease. Otherwise - } \\
\text { the provision of services. } \\
\text { Exception: short-term leases and leases of low- } \\
\text { cost properties - the requirements of IFRS } 16 \\
\text { may not be applied. }\end{array}$ \\
\hline
\end{tabular}

Source: summarized by the authors

The general basis of classification (column 2 of Table 3) in IFRS 16 (column 3) is preserved only for the position of the lessor. As for the tenant, the difference is significant.

Instead, IAS 17, P (S) of Accounting 14, NP (S) of Accounting PS 126, IPSASB 13 is based on 2 models of accounting for lease transactions given classification in the Table 3 with a traditionally simplified approach to accounting for operating leases (Figure 1). 
INDEPENDENT JOURNAL OF MANAGEMENT \& PRODUCTION (IJM\&P)

http://www.ijmp.jor.br

v. 12, n. 6, Special Edition ISE, S\&P - November 2021

ISSN: 2236-269X

DOI: 10.14807/ijmp.v12i6.1762

\begin{tabular}{|c|c|c|}
\hline \multicolumn{3}{|c|}{ Financial lease } \\
\hline Lessee & $\Leftrightarrow$ & Landlord \\
\hline \multicolumn{3}{|c|}{ Statement of financial condition } \\
\hline Leased asset + liability & & Accounts receivable \\
\hline \multicolumn{3}{|c|}{ Statement of comprehensive income } \\
\hline $\begin{array}{l}\checkmark \text { depreciation } \\
\checkmark \text { financial costs }\end{array}$ & & $\begin{array}{l}\checkmark \text { financial income } \\
\checkmark \text { profit from sales }\end{array}$ \\
\hline \multicolumn{3}{|c|}{ Operating lease } \\
\hline Lessee & $\Leftrightarrow$ & Landlord \\
\hline \multicolumn{3}{|c|}{$\underline{\text { Statement of financial condition }}$} \\
\hline $\begin{array}{l}\text { Accruals on payments or } \\
\text { prepayments are provided }\end{array}$ & & $\begin{array}{l}\checkmark \quad \text { leased asset } \\
\quad \checkmark \text { accrual / prepayment }\end{array}$ \\
\hline \multicolumn{3}{|c|}{ Statement of comprehensive income } \\
\hline$\checkmark$ operating lease costs & & $\begin{array}{l}\checkmark \text { depreciation } \\
\checkmark \text { income from operating lease }\end{array}$ \\
\hline
\end{tabular}

Figure 2: The model of accounting for lease transactions under IAS 17, P (S) of Accounting 14, NP (S) of Accounting PS 126, IPSASB 13

Source: summarized by the authors

Unlike other standards, IFRS 16 does not provide for the distribution of leases from the position of the lessee, all leases are accounted for according to a single model (Figure 3). In accordance with IFRS 16, a new category of assets arises - the asset from the right of use, which should be measured and reported in the financial statements at the reporting date. The standard provides for measurement at the date of recognition - at cost, and at the date of financial reporting or at cost or at revalued cost (according to the method recorded in the accounting policy).

In addition, such an asset is depreciated over the term of the lease. In the reporting, it can be presented either as a separate category of “Assets on the right of use”, or as part of the fixed assets of the relevant group. We emphasize the greater validity of the first approach. Depending on the decision made, the accounting technique is built: either through the opening of a separate account for assets of this type, or on sub-accounts of the second order of fixed assets accounts. 
INDEPENDENT JOURNAL OF MANAGEMENT \& PRODUCTION (IJM\&P)

http://www.ijmp.jor.br

v. 12, n. 6, Special Edition ISE, S\&P - November 2021

ISSN: 2236-269X

DOI: 10.14807/ijmp.v12i6.1762

\begin{tabular}{|c|c|}
\hline \multicolumn{2}{|c|}{ Statement of financial condition } \\
\hline Assets & Liabilities \\
\hline The right to use the asset & Commitment to make payments \\
\hline Amortization & Total costs of the lessor related leases \\
\hline+ & \\
\hline Interest & \\
\hline+ & \\
\hline Variable lease payments & Statement of Cash Flows \\
\hline Repayment of the current part of the debt - as part of operating activities \\
\hline Repayment of accrued financial expenses is part of financial activities \\
\hline
\end{tabular}

Figure 3: The impact of the lease accounting model in accordance with IFRS 16 on the lessee's financial statements

Source: summarized by the authors based on source analysis

The model meets modern user requirements, so we believe that the basic foundations of the model have every reason to be implemented in the accounting of public sector enterprises. Let's try to give arguments.

Thus, many years of careful analysis of IFRS companies' reports by representatives of the International IFRS Board, as well as other experts and scholars (Dziuba, 2019; Ostapenko, 2019; Zanoza, 2019), identified a number of key issues of the accounting model under IAS 17:

a) rental costs do not contain a financial component;

b) the financial statements do not provide information about the lease obligations assumed by the company;

c) financial statements do not show the existence of an asset, the right to use which the company has, and which is directly involved in creating value added.

As a result, there is a partial distortion of financial statements, in particular: operating profit and, as a result, the profitability of operating activities, overall liquidity, the ratio of financial independence. 
As we have already determined, the key ideas of IAS 17 (except for some nuances) are laid down in P (S) of Accounting 14, NP (S) of Accounting PS 126, IPSASB 13, so the identified shortcomings can be extended to them.

Instead, the practical implications of the lessee's application of the accounting model in accordance with IFRS 16 are:

- $\quad$ asset growth;

- increase in debt;

- decrease in the lessee's income in the first years of the lease of assets and increase at the end.

To confirm the relevance of IFRS 16 in time, we note that the US currently uses the standard ASC 842. It was developed in parallel with IFRS 16 and is based on similar principles for recognizing leases on the balance sheet. Of course, there are some features that differ from IFRS 16 (for example, ASC 842 does not provide an exception for short-term and low-cost leases; differences in sublease accounting; somewhat different approaches to disclosure; the concept of operating leases is retained, but in this case control is only over the use of the underlying asset rather than over the asset itself), but in general the approaches are similar.

Thus, we believe that the requirements of IFRS 16 are quite acceptable for application by state-owned enterprises of Ukraine. Otherwise, the performance of similar enterprises in the public and private sectors will lose comparability. For government agencies, the cornerstone is the harmonization / convergence of requirements in the chain: NP (S) of Accounting PS 126 - IPSASB 13 - IFRS 16.

It should be noted that the process of convergence of national standards for the public sector with international ones, which is relevant at the moment, is considered debatable. A direct question arises from it: would the decision on full implementation of IFRS for the public sector in domestic practice not be more reasonable and expedient? In addition, the IPSASB system is currently discussing and meeting meetings to bring the standards in line with similar IFRSs and all their current updates. The International Financial Reporting Standards Board for Public Sector Organizations (IPSASB) is currently working on an analogue of IFRS 16, but for the public sector. 
In our opinion, this is the most compelling argument that confirms the direction of movement towards a single lease model in accordance with the basic requirements of IFRS 16. And the public sector of Ukraine should not be outside these global processes. Regarding the consideration by IPSASB members not only of the basic versions of the standards, but also of their latest updates, 2020 showed that this is extremely relevant for IFRS 16.

Thus, in May 2020, the IFRS Board published amendments to IFRS 16 related to the COVID-19 pandemic, the official translation of which was published on the website of the Ministry of Finance. The reasons for the amendments were extremely common in MarchMay 2020 lease concessions in favour of the tenant: given the difficult financial situation, landlords resorted to measures to defer payment, reduce the amount or cancel the payment for a certain period.

These changes are related to the addition of 16 new paragraphs (46A, 46B, 60A, B1A, B20A, B20B) to IFRS with the following key idea: the company has every reason to apply practical simplifications and does not take into account changes in lease payments as a modification of the lease. It is allowed not even to evaluate the achievement of the criteria for the application of the modification.

This example shows that in the context of choosing the path of full implementation of IFRS for the public sector, dynamic changes and refinements will be more quickly implemented in domestic practice. Given the use of NP (S) of Accounting PS, even if they comply with international standards, there will be no full opportunity to quickly reflect such changes.

Returning to the main issue within this study, we believe that the revolutionary accounting model laid down in IFRS 16 has many advantages and every reason to be applied to the public sector in terms of requirements for:

a) Defining the nature and compliance with the basic conditions under which the contract is leased (paragraph 9 of IFRS 16). At the same time, we do not deny taking into account in addition to the manual on the definition of the contract as a lease agreement (paragraph B9-B31 of IFRS) certain nuances of the lease of state property. Thus, Vysochan and Redko (2018) emphasize that the procedure for concluding a lease agreement, one of the parties to which is a public sector entity, is a rather time-consuming process, which is regulated by the Law of Ukraine "On state lease and communal property". 
b) Application by the lessee of a single accounting model with recognition of the asset for the right of use and the lease obligation (paragraph 22 of IFRS 16). But in the rules of their initial and subsequent assessment, you can use a flexible approach, taking into account the peculiarities of accounting in the public sector and consideration of the feasibility of using certain simplifications.

c) Use of exemptions similar to IFRS 16: low-value assets and short-term leases (paragraphs 5-8 of IFRS 16). Of course, the concept of low-value assets can take into account the specifics of the public sector in determining the term of the lease and discount, as well as focus not only on value but also on the nature of assets.

d) Delimitation of the terms "modification of the contract" (in accordance with the provisions of paragraph 44 of IFRS 16) and "variable lease payments" in the context of their accounting.

e) Preservation of the approach to the classification of the lease into financial and operating for the lessor (paragraph 61 of IFRS 16). In fact, for most government agencies, the landlord's lease is key. Such entities are often landlords due to the availability of significant areas of real estate that are not used for their own needs.

f) Improved approaches to information disclosure (paragraph 53 of IFRS 16).

\section{CONCLUSIONS AND RECOMMENDATIONS}

Thus, the relevance of lease transactions for public sector entities is not in doubt, as is the need to bring the accounting of such transactions to modern requirements. IFRS 16 contains objectively the best policies for accounting for lease to date. Of course, this standard has many practical nuances that still remain open, and its individual paragraphs are difficult to interpret unambiguously.

However, the IFRS Board and the Interpretations Committee are constantly working to improve them. Therefore, we believe that the basic approaches of IFRS 16 can reasonably be implemented in the International Accounting Standards for the public sector (and such a process is already underway), and taken into account in the reflection of lease transactions by domestic public sector entities.

\section{REFERENCES}

Aurora, C. (2016). Lease accounting under IFRS 16 and IAS 17 - a comparative approach. The Journal Contemporary Economy, 78-84. Retrieved from http://www.revec.ro/papers/170205.pdf. Access: 10 August, 2021. 
Ching, L., Henga1, C., \& Noronhab, C. (2011). The impact of the new Accounting Standards for Business Enterprises (ASBE) on financial results of mainland Chinese listed companies. Advances in Accounting, 27(1), 156-165.

Dziuba, O. M. (2019). Osoblyvosti vprovadzhennia MSFZ 16 «Orenda» [Peculiarities of IFRS 16 «Leases» implementation]. Skhidna Yevropa: ekonomika, biznes ta upravlinnia, 4(21), 549-552.

Hospodarskyi kodeks Ukrainy [Commercial Code of Ukraine]: Zakon Ukrainy № 436-IV vid 16.01.2003p. Retrivied from: https://zakon.rada.gov.ua/laws/show/436-15\#Text.

International Accounting Standard 17 «Leases». Retrieved from https://mof.gov.ua/storage/files/IAS-17_ukr_2016.pdf. Access: 05 August, 2021.

International Accounting Standard for public sector 13 "Rent". Retrieved from https://buhgalter911.com/public/uploads/normativka/Standart_gossektor/\%D0\%9C\%D0\%A1 \%D0\%91\%D0\%9E\%D0\%94\%D0\%A1/\%D0\%9C\%D0\%A1\%D0\%91\%D0\%9E\%D0\%94\% D0\%A1_13.pdf. Access: 27 May, 2021

IPSAS-IFRS Alignment Dashboard IPSASB Meeting (December 2020). Retrieved from https://www.ifac.org/system/files/meetings/files/A.3-IPSAS-IFRS-Alignment Dashboard_Final_1.pdf. Access: 11 August, 2021.

Khomuliak, T. I. (2010). Problemy vprovadzhennia mizhnarodnykh standartiv v derzhavnomu sektori [Problems of implementation of international standards in the public sector]. Visnyk ZhDTU, 3 (53), 258-262.

Kints, L., \& Spoor, L. (2019). Leases on balance, a level playing field? Advances in Accounting, 44, 3-9.

Kusano, M. (2020). Does recognition versus disclosure affect risk relevance? Evidence from finance leases in Japan. Journal of International Accounting, Auditing and Taxation, 38, 224-235.

Law of Ucraine on Accounting and Financial Statements in Ukraine: Zakon №996-XIV vid 16.07.1999 r. Retrivied from https://zakon.rada.gov.ua/laws/show/996-14. Access: 10 June, 2021.

Leases: Overview of ASC 842. Retrivied from: https://rsmus.com/what-wedo/services/assurance/financial-reporting-resource-center/leases-overview-of-the-newguidance.html.

Liviu-Alexandru, T. (2018). The Advantages that IFRS 16 Brings to the Economic Environment. «Ovidius» University Annals, Economic Sciences Series, XVIII(1), 510-513. Retrivied from http://stec.univ-ovidius.ro/html/anale/RO/wp-content/uploads/2018/08/142.pdf. Access: 03 August, 2021.

Lovinska L. H. (2020). Mizhnarodni standarty finansovoi zvitnosti v obliku derzhavnykh pidpryiemstv Ukrainy [International standards of financial statements in accounting of stateowned enterprises of Ukraine]. Finansy Ukrainy, 6, 75-92. [in Ukrainian]

Milian, J., Lee, E. (2020). Did the Recognition of Operating Leases Cause a Decline in Equity Valuations? Available at SSRN. DOI: http://dx.doi.org/10.2139/ssrn.350937.

Mizhnarodnyi standart finansovoi zvitnosti 16 «Orenda» [International Financial Reporting Standard 16 «Leases»] (pereklad ukrainskoiu movoiu - 2018 rik). Ministerstvo finansiv Ukrainy. Retrieved from: https://mof. gov.ua/storage/files/IFRS16-ukr_AH-compressed1.pdf. Access: 03 August, 2021. 
INDEPENDENT JOURNAL OF MANAGEMENT \& PRODUCTION (IJM\&P)

http://www.ijmp.jor.br

v. 12, n. 6, Special Edition ISE, S\&P - November 2021

ISSN: 2236-269X

DOI: 10.14807/ijmp.v12i6.1762

Morales-Díaz, J., \& Zamora-Ramírez, C. (2018). Effects of IFRS 16 on Key Financial Ratios: A New Methodological Approach. Accounting in Europe. 15(1), 1-33. Retrieved from https://papers.ssrn.com/sol3/papers.cfm? abstract_id=2942326. Access: 11 August, 2021.

Musumeci, J., \& O'Brien, T. (2019). Lease versus Buy Analyses: Clarifying the Impact of Tax and Borrowing Rates. Managerial Finance, 45(5), 686-696. University of Connecticut School of Business Research Paper No. 18-26. Retrieved from

https://ssrn.com/abstract=3253965. Access: 06 August, 2021.

Natarajan, P., \& Kuniparambil, M. (2019). Accounting Operating Lease- A Constructive Capitalisation Strategy. Retrieved from: https://ssrn.com/abstract=3403422 Access: 12 August, 2021.

Natsionalne polozhennia (standart) bukhhalterskoho obliku v derzhavnomu sektori 126 «Orenda» [ National Regulation (Standard) of Accounting in the Public Sector 126 "Rent"]: nakaz Ministerstva finansiv Ukrainy vid 24.12.2010 r. № 1629. Verkhovna Rada Ukrainy. Retrieved from https://zakon.rada.gov.ua/ laws/show/z0091-11. Access: 10 August, 2021.

Ofitsiinyi sait DP «Ukrinterenerho» [Official site of SE "Ukrinterenergo"]. Retrieved from https://uie.kiev.ua. Access: 10 August, 2021.

Ofitsiinyi sait Ministerstva rozvytku ekonomiky, torhivli ta silskoho hospodarstva Ukrainy [Official website of the Ministry of Economic Development, Trade and Agriculture of Ukraine]. Retrieved from https://www.me.gov.ua. Access: 09 August, 2021.

Ostapenko, Yu.P. Novi pidhody do obliku orendy za pravylamy MSFZ 16 «Orenda» [New approaches to rent accounting under IFRS 16 «Leases»]. Retrieved from http://dspace.tneu.edu.ua/bitstream/ 316497/29545/ 1/89.PDF. Access: 20 July, 2021.

Pardo, F., \& Giner, B. (2018). The capitalization of operating leases: Analysis of the impact on the IBEX 35 companies. Intangible Capital, 14(3). Retrivied from:

https://www.intangiblecapital.org/index.php/ic/article/view/1168/ 727.

Pro orendu derzhavnoho ta komunalnoho maina [On lease of state and municipal property]: Zakon Ukrainy vid 03.10.2019 r. № 157-IX. Verkhovna Rada Ukrainy. Data onovlennia: 03.10.2019. Retrieved from https://zakon.rada.gov.ua/laws/show/157-20\#n475. Access: 01 August, 2021.

Pro orendu zemli [On land lease]: Zakon Ukrainy vid 06.10.1998 r. № 161-XIV. Verkhovna Rada Ukrainy. Data onovlennia: 13.02.2020. Retrieved from https://zakon.rada.gov.ua/ laws/show/161-14. Access: 16 August, 2021.

Pro skhvalennia Stratehii modernizatsii systemy bukhhalterskoho obliku ta finansovoi zvitnosti v derzhavnomu sektori na period do 2025 roku [On approval of the Strategy for modernization of the accounting system and financial statements in the public sector for the period until 2025]: Rozporiadzhennia Kabinetu Ministriv Ukrainy vid 20 chervnia 2018 r. № 437-r. Retrieved from https://zakon.rada.gov.ua/laws/ show/437-2018-\%D1\%80\#Text. Access: 02 July, 2021. [in Ukrainian]

Qu. X., \& Zhang, G. (2010). Measuring the convergence of national accounting standards with international financial reporting standards: The application of fuzzy clustering analysis. The International Journal of Accounting, 45(3), 334-355.

Regulations (standard) of accounting 14 "Leases". Retrivied from: https://zakon.rada.gov.ua/laws/show/z0487-00. 
Segal, M., \& Naik, G. (2019). The expected impact of the implementation of International Financial Reporting Standard (IFRS) 16 - Leases. Journal of Economic and Financial Sciences, 12(1), 457-463.

Stasyshyn, A. V., Dubyk, V. Ya., \& Barska, I. V. (2018). Derzhavnyi sektor ekonomiky Ukrainy: problemy ta suchasnyi stan rozvytku [Public sector of the Economy of Ukraine: problems and current state of development]. Molodyi vchenyi, 10 (62), 889-893. [in Ukrainian]

Tax Code of Ukraine. Retrieved from https://zakon.rada.gov.ua/laws/ show/2755-17. Access: 02 August, 2021.

Tsenkler, N. I., Vyhivska, I. V., \& Makarovych, V. K. (2019). Tendentsii rozvytku bukhhalterskoho obliku v derzhavnomu sektori: mizhnarodnyi kontekst [Trends in the development of accounting in the public sector: international context]. Problemy teorii ta metodolohii bukhhalterskoho obliku, kontroliu i analizu, 2(49), 75-81. [in Ukrainian]

Veverková, A. (2019). IFRS 16 and its impacts on aviation industry. Acta Universitatis Agriculturae et Silviculturae Mendelianae Brunensis, 67(5), 1369-1377. Retrivied from: https://acta.mendelu.cz/media/pdf/actaun_2019067051369.pdf. Access: 04 August, 2021.

Vidovic, L., Baldassarri, G., Vadakoott, J., Tamminaina, P., \& Mowbray, C. (2019). How Do the New Lease Accounting Standards Affect Your Assessment of Credit Risk? S\&P Global Market Intelligence, 349-357.

Vysochan, O. S., \& Redko, M. O. (2018). Teoretychni aspekty obliku orendnykh operatsii u derzhavnomu sektori ekonomiky: poniattia, ekonomichnyi zmist, klasyfikatsiia, normatyvne rehuliuvannia [Theoretical aspects of accounting of lease transactions in the public sector of the economy: concepts, economic content, classification, regulatory regulation]. Naukovyi visnyk Mizhnarodnoho humanitarnoho universytetu. Seriia: Ekonomika i menedzhment, 30, 103-110. [in Ukrainian]

Zanoza, O., \& Zakusylo, O. (2018). Zminy v MSFZ: MSFZ (IFRS) «Orenda» [Changes in IFRS: IFRS "Lease of».] Retrieved from https://www2.deloitte.com/content/dam/ Deloitte/ua/Documents/webinar/ IFRS\%2016\%20Webinar.pdf. Access: 10 August, 2021.

Zhang, S., \& Liu, C. (2020). State ownership and the structuring of lease arrangements. Journal of Corporate Finance, 62. Access: 10 August, 2021. 